\title{
Understanding the intention of generation $Z$ on Netflix and Viu streaming services
}

\author{
Restu Ayu Mumpuni ${ }^{1}$, Anita Amaliyah ${ }^{2}$, Fasiyah Noor ${ }^{3}$, Indah Laksmiwati ${ }^{4}$, \\ Lukki Lukitawati ${ }^{5}$ \\ 1,2,3,4,5 Universitas Diponegoro, Semarang, Indonesia
}

\begin{abstract}
Information and Technological sophistication makes consumer preferences' change. In the past, TV became the only option if you wanted to watch entertainment. Now, various gadgets was available, offering internetbased entertainments. It is a huge market for wide range of products that enable multiple media consumption through combination on both traditional tech forms of media which allows individuals to retain a high level of control in their media use through on-demand media services like Netflix or Viu.This study aims to examine the affect of generation $Z$ attitude and subjective norm to their intention in using streaming services with perspective explained in Theory of Reasoned Action. Generation $Z$ is the generation who is born in the period of 1995 to 2010. The young people of $Z$ generation very familiar with updated technology since their childhood. They used to modern and sophisticated gadgets intensively. Purposive random sampling was applied to collect the data from Diponegoro University's student $(N=100)$. Further, quantitative and qualitative methods were invoked to analyze the data. The records of indepth-interview were transcribed and processed using Atlas TI. The results showed that respondents were likely less an intention nor subjectove norm in using streaming service. Thereafter, this study suggests that the content matters play an important role for generation $Z$ in using streaming service, such as Netflix and Viu.
\end{abstract}

Keywords: Theory of Reasoned Action; Subjective Norm; Gadget; Generation Z; Streaming Service

\section{Memahami intensi generasi $\mathrm{Z}$ terhadap penyedia layanan streaming Netflix dan Viu}

\begin{abstract}
ABSTRAK
Kecanggihan teknologi dan informasi telah mengubah preferensi konsumen di masa kini. Di masa lalu, TV menjadi satu-satunya pilihan ketika kita ingin menonton suatu hiburan tertentu. Berbeda dengan saat ini, bermacam-macam gawai telah tersedia serta menawarkan berbagai hiburan menarik yang menggunakan basis internet. Hal tersebut merupakan pasar yang luas untuk produk yang memungkinkan konsumsi banyak media yang memungkinkan individu mempertahankan tingkat kontrol yang tinggi dalam penggunaan media mereka melalui layanan media sesuai permintaan seperti Netflix atau Viu. Penelitian ini bertujuan untuk mengetahui pengaruh perilaku generasi $\mathrm{Z}$ dan norma subjektif pada intensi penggunaan streaming service mereka menggunakan Teori Tindakan Beralasan. Generasi Z adalah generasi yang lahir pada periode tahun 1995 hingga 2010. Mereka familier dengan teknologi mutakhir bahkan sejak masa kecil mereka. Mereka secara intensif sudah terbiasa dengan berbagai gawai yang canggih dan modern. Purposive random sampling digunakan untuk memperoleh data dari mahasiswa Universitas Diponegoro $(\mathrm{N}=100)$. Selanjutnya, metode kuantitatif dan kualitatif digunakan untuk menganalisis data dalam penelitian ini. Hasil wawancara mendalam ditranskripsikan dan diproses menggunakan Atlas TI. Hasil menunjukkan bahwa responden cenderung memiliki intensi dan norma subjektif yang rendah dalam menggunakan streaming service. Studi menunjukkan bahwa konten berperan penting bagi generasi $\mathrm{Z}$ dalam menggunakan streaming service, khususnya pada pengguna Netflix dan Viu.
\end{abstract}

Kata-kata Kunci: Teori Tindakan Beralasan; Norma Subjektif; Gawai; Generasi Z; Streaming Service

Korespondensi: Restu Ayu Mumpuni, S.I.Kom. Universitas Diponegoro. Magister Ilmu Komunikasi Jalan Erlangga Barat 7 No 33, Pleburan, Semarang Selatan, Jawa Tengah. 50241 


\section{INTRODUCTION}

Looking at digital and traditional media feud in Indonesia over time gives some remarkable results. Each year, users are spending longer on digital media consistentlynow allocating around 50 minutes longer in 2019 than 2018 (Kemp, 2019). Technology constantly grows and consumer preferences' change, make it important for media to escalate and differentiate themselves. In the past, if you wanted to watch entertainment, the only thing that was available was TV with not so many channels (Cunningham, 2017). Now that all has changed, thanks to the internet; there are dozens internet-based entertainments those can be accessed through mobile devices. It is a huge market for wide range of products that enable multiple media consumption through combination on both traditional tech forms of media which allows individuals to retain a high level of control in their media use through on-demand media services like Netflix or Iflix. Unlike streaming-based entertainment, traditional TV is considered as relationship that asks attention, commitment, time, and in return provides pleasures which count as one sided relationship (Sharma, 2016) because TV users cannot control the show and largely carries substance of satisfaction in the hands of its viewers. The rise of online streaming services such as Netflix has altered the way consumers are viewing television. From consumers aged $18-29,61 \%$ state that the primary way they view television is through streaming services on the internet (Lee et al, 2018).

For decades, TV undoubtedly become the top media in terms of daily media usage, and it still is. However, since the internet consumption, both through mobile phone and computer, has escalated sharply over the past decade, it looks as though TV's popularity could soon be coming to an end. The daily TV consumption shrink from 27 minutes to just 13 minutes in 2019. In line with the old advertising adage "money follows eyeballs", online advertising expenditure is also on the rise and, according to Zenith Media Report, surpassed TV ad spending for the first time in 2017.

Large population in Indonesia means a huge market for a wide range of products including streaming-based entertainments to reach target audience exclusively from young people. This target audience can be identified based on generation. According to Kupperschmidt, the definition of generation is a group of individuals who identify their groups based on the same year of birth, age, location, and events in these individual groups' lives that have a significant influence on their growth phase (Kupperschmidt, 2000). Generation Z is those who are able to apply all activities in 
one time (multitasking) such as running social media using cellphones, browsing using a PC, and listening to music through an earphone. Whatever they do is mostly related to a virtual world. This generation has become familiar with technology since childhood and is familiar with sophisticated gadgets that indirectly affect their personalities. Generational categories are also stated by other researchers with different labels, but generally they have the same meaning. For example, Martin \& Tulgan (2002) state that Generation $\mathrm{Y}$ is a generation born in the range of 1978, while Howe \& Strauss (2000) believe that generation $\mathrm{Y}$ is those born in 1982.This happens because of the different schemes used to group these generations as they come from different country. In this occasion the researcher will adhere to generation division based on the research of Bencsik, Csikos, and Juhez (2016) which shows the inclusion of generation $\mathrm{Z}$ in generation groups, which can be seen in table 1 .

Another research by Cilliers (2017) has categorized five different generations which are identified in the modern world. First, the Table 1 Differences in Generation

\begin{tabular}{cc}
\hline Year of birth & Generation name \\
\hline $1925-1946$ & Veteran generation \\
$1946-1960$ & Baby boom generation \\
$1960-1980$ & X generation \\
$1980-1995$ & Y generation \\
$1995-2010$ & Z generation \\
$2010+$ & Alfa generation \\
\hline
\end{tabular}

Source: Bencsik, Csikos, and Juhez (2016) traditionalists (Silent Generation or the Greatest Generation), born between 1928 and 1944, who value authority and a top-down management approach. Second, the Baby Boomer Generation, born between 1945 and 1965, who tend to be workaholics. Third, Generation X, born between 1965 and 1979, a generation who is comfortable with authority and view the work-life balance as important. Fourth, Generation Y, born between 1980 and 1995 and who generally grew up in prosperity and have technology savvy. Lastly, Generation Z, born after 1995.

The researcher classified generation $\mathrm{Z}$ as those born in 1995-2010 because in Indonesia itself, the internet first appeared in 1990 and was used by the public in 1994; therefore, the firstgeneration $\mathrm{Z}$ in Indonesia born in the mid-1990s to mid-2000s. We will focus on generation $\mathrm{Z}$ as the specific target market. They are second larger internet user after millennial generation; born and raised up with technology as their identity makes them good target audiences. Known as technologically sophisticated generation, Generation $\mathrm{Z}$ are highly connected to driven lifestyles and prolific use of social media where mobile devices portrays as their remote control for life, entertainment and world beyond screen (Arora \& Sharma, 2011). As for media consumption, the generation $\mathrm{Z}$ is the first generation that has grown up with on-demand services content availability for most of their 
lives and that's made them stream more content than other generations. They seek experience and formed by peer and social influencers on products their desires (Criterio, 2017).

Generation Z communicates mostly through video. They tend to use YouTube to search "how to" information rather than Google. For example, when they want to know how to cook a recipe, they search online for a video to tell them: no reading. Teenaged boys are giving video game lectures to thousands of other kids. Teenaged girls are political activists who have their own video platform before they're thirteen years old. This is the age of verbal communication rather than written (Gaidhani et al, 2019).

Generation $\mathrm{Z}$ are familiar in both the real and virtual worlds. They can easily shift between these two worlds, as they perceive them as corresponding to one another. The consequence of this circumstance is that representatives of Generation $\mathrm{Z}$ can easily access the information they need. They also quickly share information with others. Communication processing among them is continuous, as they use wide variety of communication devices or social media.

Generation $\mathrm{Z}$ uses multiple mobile devices for various purposes, they comment on reality, the environment, and the surroundings they live in, they manifest their opinions and attitudes using Twitter, blogs, and internet forums, and they share photos (Instagram, Pinterest, Snapchat) and films (YouTube, Instagram, Snapchat). Facebook can be used for all of above-mentioned activities. Generation $\mathrm{Z}$ not only uses the content of the Internet, but they also create and control it (Hardey, 2011).

Furthermore, according to recent study, generation $\mathrm{Z}$ tend to embrace all digital platform which makes traditional TV superseded; regardless to them, TV is defined as gallery of shows not as a box with glass and wires (Telaria Hulu, 2017). Despite the fact that digital TV audience can choose to watch according to their interests and budget (Permana et al., 2019), and watch them anytime and anywhere (Abdullah \& Puspitasari, 2018). Generation $\mathrm{Z}$ hate conventional $\mathrm{TV}$ and more into video on demand or content which is great news for streaming service company e. g. Hooq, Iflix, and Netflix (Patel, 2017) as part of an emerging industry. According to We are Social (2019) research report, Netflix and Viu streaming services came in 10 mobile apps with the largest revenue which certainly set a new trend for market share in Indonesia.

Hence, the questions remain on what factors make generation $\mathrm{Z}$ (more likely to choose streaming services over traditional TV? Such factors may include cost, environment, and gender. However, after a thorough review of past studies, there is still a lack of references 
from research article that discuss streaming services in Indonesia. While there has been endless research into traditional $\mathrm{TV}$, most of those studies concentrate on the effect of TV itself rather than compared to new media e.g., streaming services as part of digital landscape. This study aims to examine the effect of generation $\mathrm{Z}$ attitude and subjective norm to their intention in using streaming services with perspective explained in Theory of Reasoned Action. The concept of intention therefore assumes to capture a range of motivational factors before performing certain behavior (Ajzen, 1991).

This study will be divided into 4 sections. The first section is the introduction, which also conducts a general brief of overview on how the idea of streaming services and generation $\mathrm{Z}$. The second section discusses the state of play or theoretical background. Thereafter, it describes the research methodology and discusses the key empirical findings. Lastly, it presents the discussion on relevant implications, limitations, and future research studies. This then followed by recommendation and conclusion.

\section{METHODOLOGY}

This study utilized both quantitative and qualitative methods. The use of both is beneficial because quantitative methods provide a high level of measurement precision, while qualitative methods supply greater depth of information (Matveev, 2002). The interview process was managed right after they fill the survey to explore more about their answer related to the questionnaire. This research was conducted in Semarang as a study area, where the population is generation $\mathrm{Z}$ who are streaming services users. Data and sampling used is closed online questionnaire and face to face interview. The instruments are combination of questionnaire and in-depth interview. The respondents survey target was $120, \mathrm{n}=100$, interviewed by six interviewee. Purposive random sampling was applied to produce a sample from each faculty so that it can be logically assumed to be representative of the population. The researchers collect the data from Diponegoro University's student with population of 55.743 students. Diponegoro University'students who are streaming service users was selected as sample of this research. For interview data collecting, snowball sampling was used. Descriptive statistic, crosstabulation, and atlas TI network coding analysis are the tools of analysis.

\section{RESULT AND DISCUSSION}

The Effect of Attitudes on the Intention in Using Streaming Service Attitudes are one of the key determinants of behavioral intention and refer to the way people feel towards a particular 
behavior. Attitudes are one's performance in behavior compared to general performance (Fishbein \& Ajzen, 2011). This is determined through consideration of one's belief about considerations arising from interaction and evaluation of the desire. A positive evaluation on streaming service will surely be able to give positive affect someone's intention in using streaming service.

To examine the affect of generation $\mathrm{Z}$ attitude and subjective norm to their intention in using streaming services, the researchers use Theory of Reasoned Action (TRA). The theory was first proposed by Ajzen and Fishbein (1980) which states that a person's actions are a realization of someone's desire or intention to act. The factors that influence intentions are attitudes on behavioral actions and subjective norms concerning one's perceptions of whether other people considered important will influence their behavior (Fishbein \& Ajzen, 2011).

In 1988, Ajzen developed the theory of reasoned action by adding individual trust and individual perceptions of behavioral control, namely the belief that individuals can perform a behavior based on the ability to do it. Essentially, this theory includes three main things. The first one is the belief in the possibility of results and evaluation of these behaviors (behavioral beliefs). The second is the belief in the expected norms and the motivation to fulfill the desired expectations (normative beliefs), and the last one is the beliefs about factors that can support or consider the awareness of the power of these factors (control beliefs) (Lee \& Kotler, 2011). Theory of Reasoned Action is based on the assumption that humans are rational beings, and they use the available information systematically. They consider everything that will possibly occur before finally deciding to do so. It is explained in this theory that behavior is influenced by will / intention in building the behavior and also that a will is a function of attitudes on subjective behavior and norms. Based on the above definition, the researcher concludes that this theory focuses on intentions determined by subjective attitudes and norms, which means that individual actions are influenced by the intentions of the individual itself where the intention is formed from subjective attitudes and norms. If the theory of reasoned action is applied to the intention of the use of streaming services media in Indonesia, the best predictor in showing how much individual intention to use streaming services is the intention to be involved in using them based on individual attitudes in using the services. Furthermore, the amount of social pressure motivates individuals to use streaming services. This attitude will lead to behavior that measures the extent to which behavior is sure or not sure, like or dislike. The attitude factors here include 
beliefs, knowledge, emotional, and behavior. So this individual attitude will influence their decision in purchase intention. The more positive the individual's beliefs about the results of an object, the more positive the individual's attitude towards the object will be. Subjective norm is a person's belief in the norms related to the object of attitude. The objects of attitude here are trust, knowledge, education level, income level and others (Prihapsara, 2017). This subjective norm will measure the influence of others to what extent in influencing their decision to watch by using a streaming service application. The closer the individual's social relationship is, the more positive the individual believes in the ideas of the closest people. So this norm forms a subjective norm in him/her that will eventually shape his/her behavior to believe in an object.

Based on this explanation above, this study proposed hypothesis 1, that is: Hypothesis One: Attitudes strongly affect on the intention in using streaming service.

The Effect of Subjective Norms on the Intention in Using Streaming Service. Subjective norm is determined by the total set of accessible normative beliefs concerning the expectations of important referents. These subjective norms are also called normative beliefs (Yousafzai et al., 2010)theory of planned behavior (TPB. The subjective norms are basically a social impact made by someone who has the closest relationship (family, friends, colleagues, etc.) that may have an influence in decision making. The subjective norm influences the desire or intention to act (Fishbein \& Ajzen, 2011). In this study the intention on watching streaming service influenced by colleagues, friend, or family. Based on explanation above, the hypothesis 2, is: Hypothesis Two: Subjective norm strongly affect on the intention in using streaming service.

\section{Streaming Services User Surveys. All} survey participants were undergraduate student of Diponegoro University. Since the aim of this study was to examine the direct influence of generation $\mathrm{Z}$ attitude and subjective norms to their intention using streaming services, only student who was born between 1995 2000 were choose. The participants received a WhatsApp message with online questionnaire link. Total 100 responses were received. The survey was conducted between May 15 until 20, 2019. Most survey questions and statement were closed-ended (e.g. 'I will do anything to watch specific streaming services content when everyone is watching it too.') and measured on a 7-point Likert-type scale (1: strongly agree, 4: so-so, and 7: strongly disagree). The student respondent was predominantly female $(n=66)$. Table 2 present a breakdown demographic of the sample. 
Table 2 Socio-economic Profile of Respondent $(\mathrm{N}=100)$

\begin{tabular}{lll}
\hline \multicolumn{1}{l}{$N$} & Percent \\
\hline Gender & & \\
Male & 34 & 34 \\
Female & 66 & 66 \\
Age (years) & & \\
18 & 7 & 7 \\
19 & 16 & 16 \\
20 & 18 & 18 \\
21 & 22 & 22 \\
22 & 20 & 20 \\
23 & 2 & 2 \\
24 & 15 & 15 \\
Monthly Expenses (Rupiah) & & \\
Less than Rp. 2.000.000 & 69 & 69 \\
Rp. 2.000.000 - 5.000.000 & 31 & 31 \\
Monthly Streaming Services & & \\
Plan (Rupiah) & & \\
Less than 100.000 & 77 & 77 \\
100.000-500.000 & 23 & 23 \\
More than 500.000 & 0 & 0 \\
Streaming & & \\
Subscriptions (Years) & & \\
Less than 1 & 59 & 59 \\
More than 1 & 41 & 41 \\
\hline
\end{tabular}

Operational Variables. Quantitative study concerned with variables related to generation $\mathrm{Z}$ intention on using streaming services instead of television. Their attitude, subjective norms and intention on using streaming services were measured using Ajzen and Fishbein's Theory of Reasoned Action equation (Fishbein \& Ajzen, 2011). It suggests that attitude, subjective norms, and intention will best measure if the behavior of interest were clearly defined, in this case were generation $\mathrm{Z}$ behavior of using streaming services instead of television.

Attitude. Consistent with Ajzen and Fishbein, two aspects of attitude were measured: (a) perceived of usefulness and (b) perceived of ease of use. Ratings were made on a likerttype scale, ranging from "strongly agree" to "strongly disagree".

Source: Research data, 2019

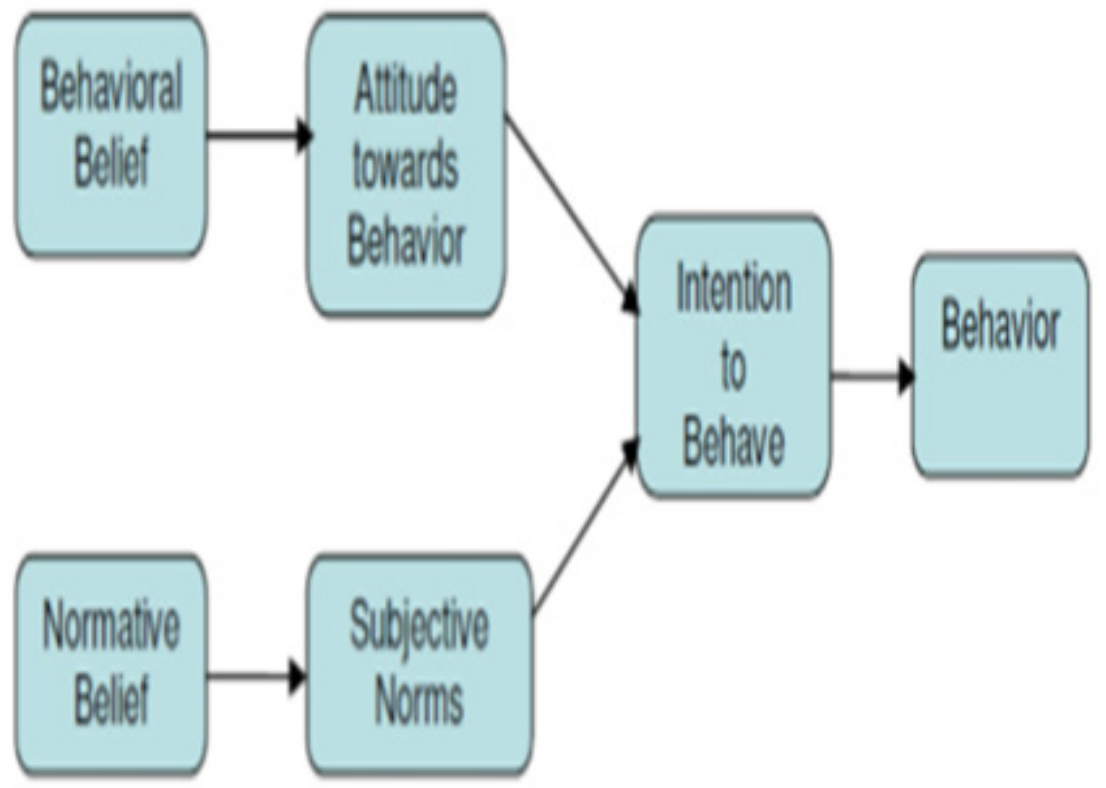

Source: Research data, 2019

Picture 1 Operational Variables

Understanding the intention of generation $\mathrm{Z}$ on Netflix and Viu streaming services (Restu Ayu Mumpuni, Anita Amaliyah, Fasiyah Noor, Indah Laksmiwati, Lukki Lukitawati) 
Subjective Norms. This study measured two aspects of subjective norms: (a) the respondent's perceptions of norms that specific held for them and (b) motivation to comply with each of their social connection or referent. Referent norms for streaming services were measured with eight items: "How much do you care what your romantic partner / family / friends think that you should watch specific content in streaming services. ". Ratings were made on a likert-type scale, ranging from "strongly important" to "strongly unimportant".

Intention. Behavioral intention using streaming services instead of television was measured with 11 items developed by Azjen and Fishbein; starting from intention to behave up to the intention to influence others. The items rating was made in a likert-type scale, ranging from "strongly likely" to "strongly unlikely".

Descriptive Statistics of the Operational Variables. To analyze reliability, statements and questions from the survey questionnaire were analyzed for validity and reliability, along with their Cronbach's $\alpha$ values. Descriptive statistic for all survey measures, shown in Table 3.

In order to examine the hypotheses and research question and correlation between variables, this study used cross tabulation. All quantitative data analysis was processed using SPSS.

Streaming Service Interview. In-depth
Table 3 Descriptive Statistics of Survey Measures

\begin{tabular}{|c|c|c|c|}
\hline & Cronbach's $\alpha$ & $M$ & SD \\
\hline Intention & .851 & & \\
\hline Question 1 & & 3.65 & 1.344 \\
\hline Question 2 & & 2.49 & 1.453 \\
\hline Question 3 & & 2.84 & 1.631 \\
\hline Question 4 & & 2.37 & 1.488 \\
\hline Question 5 & & 4.01 & 1.738 \\
\hline Question 6 & & 3.80 & 1.803 \\
\hline Question 7 & & 3.09 & 1.577 \\
\hline Question 8 & & 3.18 & 1.690 \\
\hline Question 9 & & 2.13 & 1.440 \\
\hline Question 10 & & 3.48 & 1.909 \\
\hline Question 11 & & 3.09 & 1.718 \\
\hline Attitude & .878 & & \\
\hline Question 1 & & 2.22 & 1.160 \\
\hline Question 2 & & 2.98 & 1.670 \\
\hline Question 3 & & 2.40 & 1.247 \\
\hline Question 4 & & 2.33 & 1.155 \\
\hline Question 5 & & 2.16 & 1.195 \\
\hline Question 6 & & 2.07 & 1.200 \\
\hline Subjective Norms & .877 & & \\
\hline Question 1 & & 3.85 & 1.696 \\
\hline Question 2 & & 3.66 & 1.578 \\
\hline Question 3 & & 2.86 & 1.484 \\
\hline Question 4 & & 3.38 & 1.469 \\
\hline Question 5 & & 4.39 & 1.723 \\
\hline Question 6 & & 4.36 & 1.605 \\
\hline Question 7 & & 4.34 & 1.881 \\
\hline
\end{tabular}

Source: Research Data, 2019

interviews were conducted for the qualitative research component. In order to reflect the current Diponegoro University student gender ratio, 6 six student - 2 male, 4 female - were selected via a snowball sampling method, which is used to make statistical inferences about various aspects of the relationships present (Goodman, 1961). The first interviewee was randomly selected and acted as informant who recommended the next interviewee. This process continued for the 
recruitment of all other interviewees. Most of the interviewees was using streaming services more than one year, enabling them to make a deep statement about their attitude, perceived norms, and intention toward streaming services. The interviews were approximately $20 \mathrm{~min}$ in length and were conducted from May 20-21, 2019. All the interviews transcript then coded and analyze using Atlas Ti. All interviewee information shown in Table 4.

Table 4 Interviewee Information.

\begin{tabular}{lll}
\hline Gender & $\mathrm{N}$ & Percent \\
\hline Male & 34 & 34 \\
Female & 66 & 66 \\
\hline
\end{tabular}

Source: Research Data, 2019

Table 5 Interviewee Information

\begin{tabular}{lll}
\hline Interviewee & Sex & Age (Years) \\
\hline A & Male & 23 \\
B & Female & 21 \\
C & Female & 21 \\
D & Female & 20 \\
E & Male & 24 \\
F & Female & 20 \\
\hline
\end{tabular}

Source: Research Data, 2019

\section{RESULTS AND DISCUSSION}

The first hypothesis in this study states that generation $\mathrm{Z}$ intention has strongly affected by their attitude in using streaming service. Based on the results of statistical descriptive tests, each indicator in the intention variable has an average value of 3.103 which means that generation Z's intention to watch something by using streaming service is still relatively low
Tabel 6 Descriptive Statistics Variables' Relation

\begin{tabular}{|c|c|c|c|}
\hline \multicolumn{4}{|c|}{ Intention and Subjective Norms (\%) } \\
\hline & $\begin{array}{l}\text { Not- } \\
\text { affected by } \\
\text { Subjective } \\
\text { Norms }\end{array}$ & $\begin{array}{l}\text { Affected by } \\
\text { Subjective } \\
\text { Norms }\end{array}$ & $\begin{array}{l}\text { Very } \\
\text { Affected by } \\
\text { Subjective } \\
\text { Norms }\end{array}$ \\
\hline Low Intention & 46,2 & 48,7 & 5,1 \\
\hline $\begin{array}{l}\text { Medium } \\
\text { Intention }\end{array}$ & 8,6 & 84,5 & 6,9 \\
\hline High Intention & 33,3 & 0 & 66,7 \\
\hline \multicolumn{4}{|l|}{ Phi $=0,580$} \\
\hline \multicolumn{4}{|c|}{ Cramer's V = 0,410 } \\
\hline \multicolumn{4}{|c|}{ Intention and Attitude (\%) } \\
\hline & $\begin{array}{l}\text { Low } \\
\text { Attitude }\end{array}$ & $\begin{array}{l}\text { Medium } \\
\text { Attitude }\end{array}$ & $\begin{array}{l}\text { High } \\
\text { Attitude }\end{array}$ \\
\hline Low Intention & 87,2 & 12,8 & 0 \\
\hline $\begin{array}{l}\text { Medium } \\
\text { Intention }\end{array}$ & 43,1 & 53,4 & 3,4 \\
\hline $\begin{array}{l}\text { High Intention } \\
\text { Phi }=0,449\end{array}$ & 33,3 & 66,7 & 0 \\
\hline Cramer's V $=0$ & 0,318 & & \\
\hline
\end{tabular}

Source: Research Data, 2019

compared to watching television or other media. The average value of generation $\mathrm{Z}$ attitude on streaming service is 2.36 , which means that the use and encouragement in generation $\mathrm{Z}$ to use streaming service is still very low. The low value of the average attitude towards the low intention value to use streaming service can be interpreted that the two variables are interrelated. Based on the results of the relationship of intention and attitude variables, the value shown by Cramer's V is even lower at 0.318 which means the relationship between the two is weak. The intention to watch broadcasts through 
streaming service is not strongly affected by the presence or absence of encouragement from the respondents. When respondents have an attitude of not paying attention to streaming services, the intention to watch is also certainly low.

However, when respondents have enough attention to streaming services, their intention to watch has increased, although not significantly. Likewise, when they have great appreciation for watching through streaming services, the intention to watch does not change from those who have a moderate appreciation attitude. The results of this study indicate that regardless of how much generation Z likes streaming services, the intention or encouragement to really watch is not strong or can be said to be weak. This is in accordance with the theory of reasoned action which states that one's intention in behaving can be influenced by two factors, namely subjective attitudes, and norms. The research data shows that the value of the attitude variable is low so the value of the variable of intention level is also low.

The second hypothesis in this study states that generation $\mathrm{Z}$ intention has strongly affected by the subjective norms to use streaming services. The statistical descriptive test results state that the average subjective norm value obtained by the closest environment of generation $\mathrm{Z}$ to streaming service is 3.83 . This means that the encouragement from outside directly or indirectly to use streaming services is still low. Based on the results of qualitative research using snowball interviews, there are two types of external influences on respondents' intentions in watching broadcasts through streaming services compared to television. The first is injunctive norms which means that when the surrounding environment encourages respondents to watch broadcasts via streaming services compared to television. The second is descriptive norms, which is when the surrounding environment does the same thing. All respondents thought that when people in the surrounding area watched one particular television show, the respondents are encouraged to do the same thing with or without the additional influence of injunctive norms. Based on the results of the relationship of intention variables and subjective norms, Cramer's V value is 0.410 which means the relationship between the two is weak. In short, the intention of someone watching show through streaming service is not strongly affected by the closest subjective norms of the environment.

Looking at the accumulated data, one can easily identify some of the general trends on why generation $\mathrm{Z}$ subscribe on streaming services. Let us first take a look at the streamers; it has become evident that; streaming services allows its subscribers or users to mitigate their needs of satisfaction by watching selected 
movies or films (41\%). This finding indicates that streaming services is an emerging way that enables viewers watch movies without going to theaters, nor going to rental stores (Chao et al., 2016).

Unlike Traditional TV, streaming services has led to a profound transformation in our ability to access and content or entertainment which mass can easily change based on their preferences or motives and broadening access to entertainment diversity. Unlike elder generation, generation $\mathrm{Z}$ has an innate comfort with the virtual world. (Wood, 2013) emphasizes that four trends are likely to characterize generation $\mathrm{Z}$ as strong tech-based consumers: 1) An interest in new technologies, 2) An insistence on ease of use, 3) A desire to feel safe, and 4) A desire to temporarily escape the realities they face. Generation $\mathrm{Z}$ sees technology as an instrument of life and innovation is to be seen as given agenda in their life. It is clear that this streaming services employ mobile phones to facilitate their services, and unlike traditional TV, its enable to do what they are already doing in a faster, more efficient and enhanced features and more flexible way (Kovacs \& Jansen, 2015).

The aim of this study is to understand the affect of generation $\mathrm{Z}$ attitude and subjective norm to their intention in using streaming services. Based on research (Arora \& Sharma, 2011) and (Telaria Hulu, 2017), the study is in line with the usage of streaming service for the $\mathrm{Z}$ generation in Indonesia. The statistical analysis results present that generation $\mathrm{Z}$ has low intention in using streaming service, while the qualitative result shows the opposite.

In general, generation $\mathrm{Z}$ intention in using streaming service is influenced by their attitude and subjective norms, varies from weak to strong. The two factors to be considered are subscription cost and educational status. It can be proven by the result in this study that indicates the generation $\mathrm{Z}$ intention in using the streaming service is still low, compared to watching television. The demographic data shows that most respondents (69\%) have allowance less than two million per month, with a budget on service streaming service less than one hundred thousand rupiahs (77\%). In Indonesia, Netflix $(21,7 \%)$ and $\operatorname{Viu}(28 \%)$ become the most popular streaming service for generation $\mathrm{Z}$ compared to others. This could be due to the subscription fee of VIU (Rp. 30,000) was cheaper than Netflix subscription fee (Rp. 109,000) (Telkomsel.com, 2019) (Pratomo, 2019). VIU offers the cheapest streaming services compared to Netflix or Iflix which is supported by interview data from some respondent. This major preferences can easily change due to flexibility, promos, and desired shows which reinforces the belief of Priporas, Stylos, \& Fotiadis (2017) about generation $\mathrm{Z}$ characteristic as less loyal consumers. As 
some respondent further explained, they have higher expectations, no brand loyalty and care more about the experience. Based on the data of streaming service providers, compared by id.techinasia.com, Netflix is the only streaming service with monthly subscription fee more than one hundred thousand rupiahs (Kurniawan, 2018). However, Netflix had launched another subscription plan with lower budget. Now user who access streaming service only by mobile phone can subscribe mobile package with only Rp. 54,000 per month. The Netflix subscribers are $21,7 \%$ of $100 \%$ who are willing to spend more money to satisfy their entertainment needs.

Thus, the cost factor becomes an important factor why they intent to watch streaming service in Indonesia.

Table 6 Variation of Subscription fee of Streaming Services in Indonesia

\begin{tabular}{lll}
\hline Platform & Subscription & Package \\
& Fee & \\
\hline Netflix & Rp 54.000 & Mobile \\
& Rp 120.000 & Basic \\
& Rp 153.000 & Standard/ HD \\
& Rp 186.000 & Premium/ Ultra HD \\
Viu & Free & Basic \\
& Rp. 30.000 & Premium \\
Disney+ & Rp. 39.000 & Monthly \\
Hotstar & & \\
& Rp. 199.000 & Yearly \\
Vidio & Rp. 29.000 & Premier Gold \\
& Rp. 49.000 & Premier Platinum \\
iFlix & Rp.39.000 & Monthly \\
GoPlay & Rp. 89.000 & Monthly \\
HBO Go & Rp. 60.000 & Monthly \\
\hline
\end{tabular}

Source: Research Data, 2019
A huge market of Indonesia makes it no winner-takes-all in this streaming service industry competition. Considering a diverse characteristic of Indonesian viewers, every streaming service contributes to the creative industry with their unique value preposition. For instance, Netflix comes with special feature for kids, original series and movies, animation, and documenter; Disney + Hotstar offers Disney movie and Hollywood; Viu wins in Asian (Indonesia, Korea, Japan, Mandarin, Thailand) movies and series; and iFlix with their movies, series, and animation. With this variation of streaming services, generations $\mathrm{Z}$ are welcome to choose which one is suitable with their preferences and budget.

Another factor to be considered is generation $\mathrm{Z}$ educational status. All respondents in this study are students. They spend their time mostly to study and join university organization. The interview shows that the respondents who have strong intention admit that their activities as a student are intense and time consuming. However, they are able to spare time to watch streaming service even in the middle of the class or before sleeping.

Qualitative research with snowball sampling method presents some interesting findings. First, content plays as an important role on generation $\mathrm{Z}$ intention in using streaming service. When they are not interested by the content offered, 
they will unsubscribe the streaming service and tend to try another alternative such as web streaming and illegal download. On the other hand, when they are satisfied, subscription fee and appearing ads are not a big deal. Generation $\mathrm{Z}$ like entertainment products that are compelling and real. They are connected and conscientious; Likely to be facilitated by technology that offer greater mobility in devices that offer escapism (eg, mobile phones with media and Internet availability) (Trifecta, 2015) and $24 / 7$ access to networks roommates inline to our study. Regarding the consumption of streaming networks, this study finds that VIU (28\%) is higher rather than Netflix (21, $7 \%)$. VIU is very heavy on Asian content such as Bollywood and Korean Drama while Netflix boasts Hollywood blockbusters, dramas Courageous and innovative original content. It suggests that VIU's content gives rise to a new dream society of "Asian" culture manifestation itself against Western domination culture (Dator \& Seo, 2004). Aside of the content availability motives, the demographics of data indicates VIU is more favorable than other streaming services because it gives free and easy payable content options.

Second, for generation $\mathrm{Z}$ with high intention, subjective norms become a reason to maintain interaction among their peers. For instance, spoiler encourage respondents to watch certain streaming service. They try to watch streaming service and keep updated before they hang out with their friends to avoid any spoilers from them. It also helps them to catch up and connect with the conversation. One of the respondents emphasizes the main reason of streaming services usage is satisfaction and being recognized and connected to their friend zones which indicates one respondent can have subscription to more than one streaming services

Social trends become one aspect that really matter of why people access online media and choose what they watch. Social media and technology allow people to connect easier and see what is trending now. Social media acts like a recommendation engine driving the discovery of streaming service content. For instance, when generation $\mathrm{Z}$ sees their friend's post about certain movies or series on Instagram, they will be curious and search the content on the streaming service that they subscribed. If not, they are most likely willing to subscribe to get access to the content. It also inspires the phenomenon of "FOMO," or "fear of missing out." Young viewers have a fear of being the only person who had not seen the show and thus of being unable to participate in the community and conversations, online and offline (Matrix, 2014).

For them, streaming services are not about 
social exile but about enabling and enhancing participation in social conversations and cliques. If they knew all their friends were talking about a particular movie or series, they would probably want to watch it too.

Research by Bondad-Brown et al. (2012) produced a statistically significant relationship between social trends of the current age and the factors of adoption. The data indicated significant correlations between social trends and how the adoption of online media appears. The social factor of digital technology, mobile apps and social media are shown to impact this loss of viewership (Feldman, 2016; Bautista et al., 2016; McCreery \& Krugman, 2015; Bondad-Brown et al., 2012)

This research gives contribution to describe the user characteristics. The cost factor and educational status of generation $\mathrm{Z}$ helps in determining the level of intention in using streaming service. Research on this topic still needs to be developed in Indonesia. The future research can explore more about various factors, such as economic, socio-cultural, educational factors. In addition, comparing the intention among streaming service providers can be another option to be explored.

\section{CONCLUSION}

There are two key points emerge from the analysis of the intention of generation $\mathrm{Z}$ on streaming service. First, the significant influence of attitude on intention variable suggested in this study is supported by usefulness and easiness of using streaming service. The content choice and quality are the integral aspects of how satisfied the streaming service users are. They are willing to pay, spend more times on watching ads, and try other streaming alternatives as long as they get access to preferred content. Second, the low intention on using streaming service weakly affected by attitude and subjective norms. On the other hand, socio-demographic attributes, such as educational status and subscription budget, should be considered.

The findings present managerial implication for streaming service provider to consider their streaming service content as an important aspect. The content is a double-edged sword that can be a favorable opportunity or a disadvantageous threat. Users who are satisfied with the content will stay and likely become loyal subscribers. On the other hand, users who are unable to fulfill their expectation on the streaming content will unsubscribe the service and try other streaming alternatives. To that end, recommendation on improving the content choice and quality is ultimately proposed. When streaming users meet their expectation, monthly fee and ads are not a big deal. Another implication, streaming service providers should come up with strategies for segmented market, 
such as students, with specific promotion considering the finding in the study that many students are unable to afford certain streaming service.

The respondent in this study is generation $\mathrm{Z}$ who is limited to 100 students in Diponegoro University and did not accommodate other educational and occupational backgrounds. This becomes a limitation of this study, which are not representative and comparable. The remaining factors of streaming service usage, such as economic, socio-culture, and education, become major issues which extends beyond the limits of this analysis and are left for future research.

\section{REFERENCES}

Abdullah, A., \& Puspitasari, L. (2018). Media Televisi Di Era Internet. ProTVF, 2(1), 101. https://doi.org/10.24198/ptvf.v2i1.19880

Agarwal, Arun \& Agarwal, Kabita \& Misra, Gourav \& Pabshetwar, Omkar. (2019). Is the Online Internet Streaming Going to Kill TV/Cable by 2025?. 7. 91-93. 10.12691/ ajeee-7-4-1.

Ajzen, I. (1991). The Theory of Planned Behavior. Organizational Behavior and Human Decision Processes, 50(2), 179-211. https://doi.org/10.1016/07495978(91)90020-T

Arora, L., \& Sharma, B. (2011). Understanding the Attitude of Generation $\mathrm{Z}$ towards Workplace. International Journal of Management, Technology and Engineering, IX(I).
Bautista, J. R., Lin, T. T., \& Theng, Y. (2016). How and why users use social TV systems? A Systematic Review of User Studies. Piscataway, NJ: IEEE. Xs

Bencsik, A., Csikos, G., \& Juhaz, T. (2016). Y and $\mathrm{Z}$ Generations at Workplaces. Journal of Competitiveness, 8(3), 90-106. https:// doi.org/10.7441/joc.2016.03.06

Bondad-Brown, Beverly A., Rice, Ronald E. \& Pearce, Katy E. (2012) Influences on TV viewing and online user-shared video use: Demographics, generations, contextual age, media use, motivations, and audience activity. Journal of Broadcasting \& Electronic Media, 56(4), 471-493.

Cebeci, U., Ince, O., \& Turkcan, H. (2019). Understanding the Intention to Use Netflix : An Extended Technology Acceptance Model Approach. International Review of Management and Marketing, 9(6), 152157.

Chao, C., Hegarty, N., \& Fray, I. (2016). Impact of Movie Streaming over Traditional DVD Movie Rental-An Empirical Study. Journal of Industrial and Intelligent Information, 4(2), 104-109. https://doi. org/10.18178/jiii.4.2.104-109

Cilliers, E.J. (2017). The challenge of teaching genera-tion Z. People: International Journal of Social Sciences, 3(1), 188-198. DOI: 10.20319/pijss.2017.31.188198

Criterio. (2017). Gen Z Report.

Cunningham, S. (2017). Iflix, Hooq, Viu, Netflix, Viki, Catchplay And More: It's A Crowded Video- On-Demand World. Forbes.Com.

Dator, J., \& Seo, Y. (2004). Korea as the wave of a future: The emerging Dream Society of icons and aesthetic experience. In Journal of Futures Studies (Vol. 9, Issue 1).

Dolot, Anna. (2018). The characteristics of 
Generation Z. e-mentor. 44-50. 10.15219/ em74.1351.

Fishbein, M., \& Ajzen, I. (2011). Predicting and Changing Behavior: The Reasoned Action Approach. In Predicting and Changing Behavior: The Reasoned Action Approach. https://doi.org/10.4324/9780203838020

Feldman, J. (2016). How we watch football. Sports Illustrated, 125(18), 36-40

Gaidhani, S., Arora, Sharma

Understanding The Attitude Of Generation $\mathrm{Z}$ Towards Workplace. International Journal of Management, Technology And Engineering. 9(1) .

Garg, R. M., Kapoor, S., \& Kumar, K. (2010). Transmitting Video-on-Demand Effectively. Universal Journal of Computer Science and Engineering Technology, 1(2), 0-5. https://doi.org/10.3850/978-981-087618-0

Goodman, L. A. (1961). Snowball Sampling. The Annals of Mathematical Statistics. https://doi.org/10.1214/aoms/1177705148

Hallinan, B., \& Striphas, T. (2016).

Recommendedforyou:TheNetflixPrizeand the production of algorithmic culture. New Media \& Society, 18(1), 117-137. https:// doi.org/10.1177/1461444814538646

Hardey, M. (2011). Generation C: Content, Creation, Connections and Choice. International Journal of Market Research, 53(6), 749-770. DOI: 10.2501/IJMR-53-6749-770.

Hasan, V. A. (2017). Analisis Faktor-Faktor Yang Mempengaruhi Willingness To Subscribe: Telaah Pada Layanan Video On Demand Netflix. Ultima Management, 9(1), 22-38.

Howe, N., \& Strauss, W. (2000). Millennials rising: The next great generation. New York: Vintage.
Kemp, S. (2019). Digital 2019: Global Digital Overview. Datareportal.Com.

Kovacs, G., \& Jansen, J. (2015). An Analysis of Strategies by Netflix in the Television Market.

Kupperschmidt, B. R. (2000). Multigeneration employees : Strategies for effective management. Health Care Manager, 19 (1), 65-76

Kurniawan, I. (2018). Ketahui Perbedaan

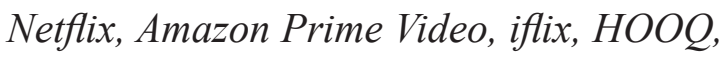
dan Lainnya Title. Id.Techinasia.Com.

Lee, C. \& Nagpal, Pankaj \& Ruane, Sinead \& Lim, Hyoun. (2018). Factors Affecting Online Streaming Subscriptions. 16.

Lee, Nancy R and Philip Kotler. (2011). Social Marketing :Influencing Behaviors for Good. US. Sage Publication, Inc.

Kupperschmidt, B. R. (2000). Multigeneration employees: Strategies for effective management. Health Care Manager, 19 (1), 65-76

Martin, C. A. Tulgan, B. (2002). Managing the Generational Mix. Amherst: HRD Press.

Matrix, Sidneyeve. (2014). The Netflix Effect: Teens, Binge Watching, and On-Demand Digital Media Trends. Jeunesse: Young People, Texts, Cultures. 6. 119-138. 10.1353/jeu.2014.0002.

Matveev AV (2002). The advantage of employing quantitative and qualitative methods in intercultural research. Russian Communication Association.

McCreery, S. P., \& Krugman, D. M. (2015). TV and the iPad: How the Tablet is redefining the way we watch. Journal of Broadcasting and Electronic Media, 59(4), 620-639

Mikos, L. (2016). Digital Media Platforms and the Use of TV Content: Binge Watching and Video-on-Demand in Germany. Media and Communication, 4(3), 154. https://doi. 
org/10.17645/mac.v4i3.542

Patel, D. (2017). Iflix, Hooq, Viu, Netflix, Viki, Catchplay And More: It's A Crowded Video- On-Demand World. Forbes.Com.

Pereira, Miguel \& Elkawy, Amer \& Lekov, Andrey \& Adhikari, Keshab. (2015). Netflix - the new face of the TV industry. 10.13140/RG.2.1.3867.4081.

Permana, R.S. M.,Abdullah,A., \& Mahameruaji, J. N. (2019). Budaya Menonton Televisi di Indonesia: Dari Terrestrial Hingga Digital. ProTVF. $\quad$ https://doi.org/10.24198/ptvf. v3i1.21220

Pratomo, Y. (2019). Netflix Uji Coba Paket Langganan Murah Khusus Smartphone. Tekno.Kompas.Com. https://tekno.kompas. com/read/2019/03/26/20090057/netflixuji-coba-paket-langganan-murah-khusussmartphone

Pradsmadji, S. I., \& Irwansyah. (2020). Media Convergence in the Platform of Video-onDemand : Opportunities, Challenges, and Audience Behaviour Konvergensi Media dalam Platform Video-on-Demand : Jurnal ASPIKOM, 5(1), 115-128.

Prihapsara, F.. (2017). The Influence of Attitude and Subjective Norm Towards The Purchase Intention as Potential Consumer of Mouthwash Product. JPSCR: Journal of Pharmaceutical Science and Clinical Research, 2(1), 6-17

Priporas, C.-V., Stylos, N., \& Fotiadis, A. K. (2017). Generation $Z$ consumers' expectations of interactions in smart retailing: A future agenda. https://doi. org/10.1016/j.chb.2017.01.058

Schweidel, D. A., \& Moe, W. W. (2016). Binge Wathcing and Advertising. Journal of Marketing. https://doi.org/10.1360/zd2013-43-6-1064

Sharma, R. (2016). The Netflix Effect : Impacts of the Streaming Model on Television Storytelling. Wesleyan University.

Tech in Asia ID. (2016). Kilas Balik Streaming Video On Demand di Indonesia Sepanjang 2016. Retrieved March 27, 2020, from https://id.techinasia.com/ layanan-streaming-video-on-demandindonesia-2016

Telaria Hulu. (2017). How Gen $Z$ Connects to TV: Exploring The Generation Divide in the Future TV.

Telkomsel.com. (2019). Paket Maxstream.

Trifecta. (2015). Generation Z Media Consumption Habits True Digital Natives. Turner, A.R.(2013). Generation Z: Technology's Po-tential Impact in Social Interest of Contemporary Youth. A Research Paper Presented to The Faculty of the Adler Graduate School, 1-79

Wayne, M. L. (2018). Netflix, Amazon, and branded television content in subscription video on-demand portals. Media, Culture and Society, 40(5), 725-741. https://doi. org/10.1177/0163443717736118

We Are Social. (2019). Digital Data Indonesia 2019. Data Reportal. https://datareportal. com/reports/digital-2019-indonesia.

Wood, S. (2013). Generation Z as Consumers: Trends and Innovation. Institute for Emerging Issues: NC State University. https://doi.org/10.1002/jcb.27136

Yousafzai, S. Y., Foxall, G. R., \& Pallister, J. G. (2010). Explaining Internet Banking Behavior: Theory of Reasoned Action, Theory of Planned Behavior, or Technology Acceptance Model? Journal of Applied Social Psychology. https://doi.org/10.1111/ j.1559-1816.2010.00615.x

Zenith Media Report. (2017) Media Consumptions Report. retrieved from zenithmedia.com 